\title{
Formulation of Marketing Communication Strategy and its Implementation in State Senior High School 10 Malang (Leadership Academy)
}

\author{
Vini Tanzah Cahyati ${ }^{1}$, Danardana Murwani ${ }^{2}$, Wahju Wibowo ${ }^{3}$ \\ ${ }^{\prime}$ (Graduate Program of Business and Management Education \\ Universitas Negeri Malang, Indonesia) \\ ${ }^{2}$ (Faculty of Economics, Graduate Program of Business and Management Education \\ Universitas Negeri Malang, Indonesia) \\ ${ }_{3}^{3}$ (Faculty of Economics, Graduate Program of Business and Management Education \\ Universitas Negeri Malang, Indonesia)
}

\begin{abstract}
This study aims to know (1) the formulation of marketing communication strategy conducted by State Senior High School 10 Malang (Leadership Academy), (2) The implementation of marketing communication strategy conducted by State Senior High School 10 Malang (Leadership Academy), (3) the supporting factor and inhibiting factor in the marketing communication activity conducted by State Senior High School 10 Malang (Leadership Academy). The study design uses qualitative study method with descriptive approach. The study results conclude that: (1) the procedure on marketing communication strategy is selecting the intended society, Identifying the society desire, determining the marketing mix including product / service, price, location and promotion (2)the implementation of marketing communication strategy focuses on one element, namely the promotion consisting of advertising, sales promotion, relation of public and publicity, as well as personal sales, (3) the supporting factors of the implementation of marketing communication strategy are the promotion media used has vast scope; it is formed a special team of school marketing; fund availability; facility; the adequate means and infrastructure; teachers with good qualification; foreign and domestic cooperation; student's of State Senior High School 10 Malang enthusiastic (Leadership Academy) as well as also as the school marketing; parents' loyalty to school so that it creates the word of mouth marketing; unique characteristic of boarding school; scholarship and achievement; while the resisting factor is high cost of education.
\end{abstract}

Keywords: strategy, communication, marketing, implementation.

\section{Introduction}

This study was aimed to investigate the concept of marketing communication for school brandof public senior high school (SMAN) 10 Malang (Leadership Academy) to the public. The brand is always easily remembered in the heads and hearts of consumers, rather than the packaging (logo) [1]. Leadership Academy was formerly taken from Sampoerna Academy, has skyrocketed and chalked many achievements both in academic and non-academic. It also brings an excellent image among the public. This certainly sparked a lot of competitors in terms of marketing. Porter [2]the essence of formulating competitive strategy is relating a company to its environment. Although the relevant environment is very broad, encompassing social as well as economic forces.This research questions to knowthe formulation of marketing communication strategy conducted by State Senior High School 10 Malang (Leadership Academy), the implementation of marketing communication strategy conducted by State Senior High School 10 Malang (Leadership Academy), the supporting factor and inhibiting factor in the marketing communication activity conducted by State Senior High School 10 Malang (Leadership Academy).

\section{Research Methods}

The process of data analysis involves describing text and image data. It involves preparing the data for analysis, getting deeper understanding,representing the data, and making interpretation of the larger meaning of the data [3]. Triangulation was conducted by comparing the different data sources of information by examining the evidence of the sources and applying it to build a coherent justification of the study [3].

\section{Research's Result And Discussion}

The Formulation of Marketing Communication Strategy In SMAN 10 Malang Leadership Academy

The intense competition leads the school to give effort so that it can win the competition by implementing appropriate competitive strategy to realize the school goals. Adopting the communication process 
model according to Kotler and Keller [4], the communication process contains the elements to be applied as marketing. Then, the researchers apply the communication process model in the strategy formulation conducted by SMAN 10 Malang as the following.

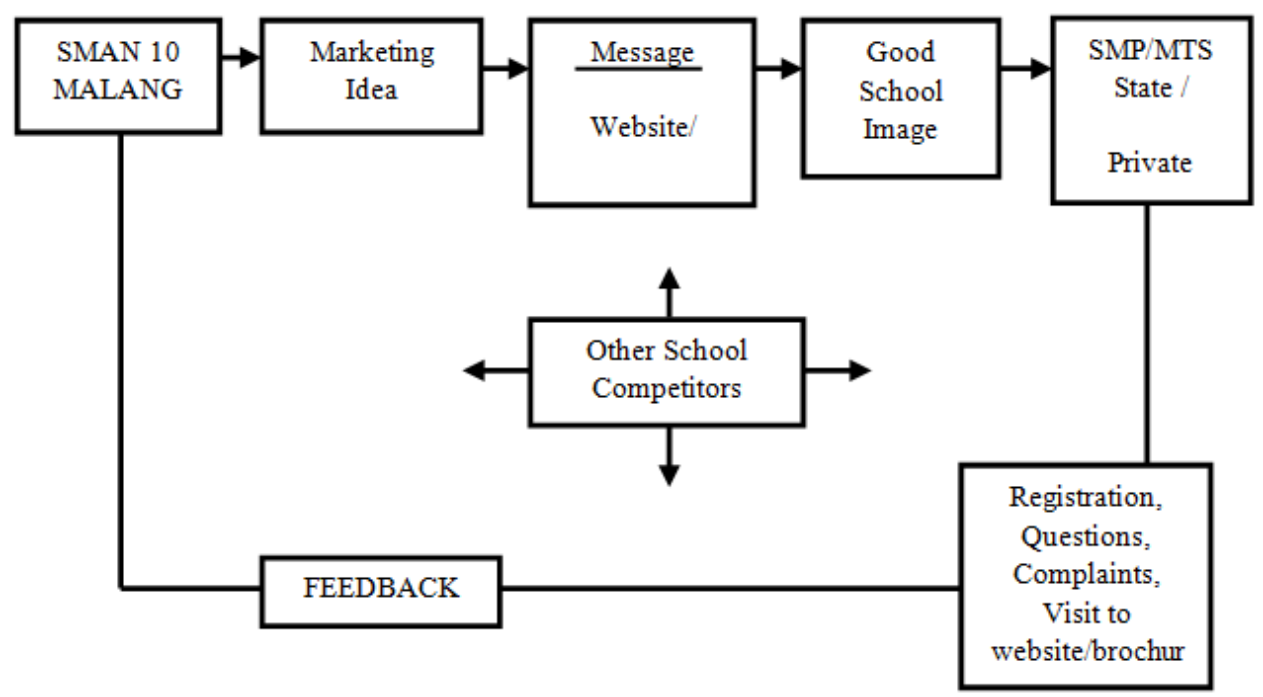

Figure 1. Marketing Communication Process Model of SMAN 10 Malang

Source: Data Processed by the Researchers, 2016

Marketing Mix applied by SMAN 10 Malang (Leadership Academy) ranging from communication product, price, place and promotion. It in accord to Grant[5] which define the competitive strategy is a combination between the end and the goal pursued by the company with tools (wisdom) where companies are trying to get there. It is in linewith [6], their findings concluded that effective communication of climate change that can motivate change in consumer behavior (not only raise further awareness) will depend on: the relevance of climate change to the lives of consumers and the relationship with their consumption behavior is being clear; the target of the strategy that takes into account the differences between the major consumer segments; and developing motivational messages from the control of the consumer rather than avoiding the perception of "greenwashing".The main purpose of marketing conducted by SMAN 10 Malang (Leadership Academy) is dedicated particularly for studentsfrom Malang resident to join the scholarship and generally for Indonesian citizen for independent admission.Reputable, qualified and well-equipped school has become public expectation. Based on the observations and data obtained by researchers, SMAN 10 Malang (Leadership Academy) has promoted some of the facilities that are rarely owned by other educational institutions, namely: the boarding school is equipped by an adequate internet access andlaboratories (physics, computer, chemistry, biology, social science, sports arena, and extra curricular equipment).

The variables used by SMAN 10 Malang (Leadership Academy) as a means to meet the needs and desires of the societywhich includesproducts/ services, admission fee, location, and promotion. Communications products applied by SMAN 10 Malang offers achievement and facilities. As the research findings conducted [7], they concluded that positioning is a key concept in marketing, branding and strategy. This is supported by Kotler \& Armstrong [8] which states that a good product is a product that is capable of describing himself as a salesman silence.Communication price set by SMAN 10 Malang relatively expensive for high school education.Communication presented a SMAN 10 Malang observed by researchers through observation showed that building visual store merchandising as claimed by Kotler \& Armstrong [8], which are the devices to symbolize the typical school in accordance with the Leadership Academy program.SMAN 10 Malang is located at Jl. Raya Tlogowaru Malang, East Java. The location is on suburb which the nuance is full of peace, the building is spacious, comfortable and beautiful.Communication campaign as the focus of discussion in marketing communications applied by SMAN 10 Malang is in accord to the opinion stated by [8]. They state that integrated marketing communications(Integrated Marketing Communications) is usually called the promotion mix (marketing mix) a company made up of a blend of specifically between advertising, personal selling, sales promotion, public relations, and direct marketing that companies use to achieve the goals of advertising and marketing. Promotion which is one element of the marketing mix (4P) which is used as the focus of the discussion of marketing communications. The marketing mix of SMAN 10 Malang (Leadership Academy) is consisting of a assimilation between the sales promotion, personal selling, advertising, and public relations.Pitta [9] suggest that their research provides information related to approaches and actions for marketing communicators that can improve the success of their promotional efforts. 
"There are 40 children was financed by Malang government. All of them are from Malang.Previously, all students from all over east Java has the same opportunity for this scholarship. Hence, only some students (40 students) are from Malang, while the rest are from all over Indonesia" ( $2^{\text {nd }}$ informant)

"We havean extra added value in terms of boarding school. Comparing to the other school, there are additional activities presented through educational school program" ( $1^{\text {st }}$ informant). "The admission fee is 2 million for Malang resident and2.5 millionfor out of Malang resident in East Java province. Then, 3 million for resident from Out of East Java province, Indonesia" ( 1 informant).

The Implementation of Marketing Communication Strategy In SMAN 10 Malang (Leadership Academy)

Marketing communication mix in SMAN 10 Malang (Leadership Academy)consisting of advertising, sales promotions, public relations \& publicity, personal selling. The following is the researchers' illustration and classification in the marketing communication mix applied by SMAN 10 Malang.

Table 1. Marketing Communication Mix by SMAN 10 Malang

\begin{tabular}{|c|c|c|c|}
\hline Advertising & $\begin{array}{c}\text { Sales } \\
\text { Promotion }\end{array}$ & $\begin{array}{c}\text { Public relation } \\
\text { \& publicity }\end{array}$ & $\begin{array}{c}\text { Personal } \\
\text { selling }\end{array}$ \\
\hline $\begin{array}{c}\text { website, } \\
\text { brochures }\end{array}$ & $\begin{array}{c}\text { Scholarship, } \\
\text { competition / }\end{array}$ & $\begin{array}{c}\text { Socialization, } \\
\text { press release, } \\
\text { sponsorship, } \\
\text { event\& } \\
\text { publicity }\end{array}$ & $\begin{array}{c}\text { Roadshowto } \\
\text { State / Private } \\
\text { SMP/MTs } \\
\text { throughout } \\
\text { Indonesia }\end{array}$ \\
\hline
\end{tabular}

Source: Data Processed by Researchers, 2016

\section{Advertising}

The forms of advertising communication applied by SMAN 10 Malang in terms of communication tools that use the website and the brochure shows non-personal nature. Peattie[6] in their study also mentioned that effective communication of climate change that can motivate change in consumer behavior will depend on the targeting strategy that takes into account the differences between consumer segments major and developing motivational messages rather than dominate the consumer. This is reinforced by the results of previous research conducted by Cox [10] who found six themes emerged from 12 qualitative data from interviews with supervisors and of the Internet on their social media usage. Further, Shimp [11] referring back to our conceptual framework for marketing communications decisions, it can be seen that the outcomes from a marcom program are twofold: enhancing brand equity and affecting behavior. It is in accord to the findings of Powers [12] who argued that the perspective of the commodity, regional, institutional, and a functionalist school on marketing that is used to describe the evolution of the electronic market as well as to give propositions to guide future research.

\section{Sales promotions}

Sales promotion is given in the form of acceptance of the scholarship through the Government of Malang and the Olympics. The findings are relevant to the research conducted by Oplatka [13]. They stated that based on the 25 studies were identified as relevant to the review, among the themes discussed in this study is scanning school environment, marketing strategies, promotion and public relations, moral dilemmas, and other forms of school in response to the competition.

\section{Public Relations \& Publications}

The marketing mix tool used in this case is through socialization by the head of SMAN 10 Malang to the representatives of Junior high school (SMP) / Islamic Junior High school(MTS) / both Public and Private school in Malang. In accord tothe results of [14] they concluded that school marketing is widely practiced in several countries, and found that the principal actively contributed on a number of marketing activities, particularly those associated with healthy productor environmentally friendly, or offering educational or social value added school enthusiasts. Kotler \& Armstrong [8] defines that Public Relation is an effort to establish good relations with the various communities around the company to get favorable publicity, fostering "corporate image" is good, and the handle or dampen rumors, stories and adverse events. In accordance with the results of 
Formulation of Marketing Communication Strategy and its Implementation in State Senior High..

Li [15] which concluded that the promotion tactic was the most effective strategy to boost the image of the school. In addition, it is an effective predictor of the parents' behavior. Finally, school image mediates the relationship between marketing tactics and parents loyalty. Tubin [16] in his research findings mentioned that the marketing of the school and its contribution to the success of schools is a contentious issue in education, and although marketing activities that take place in schools, they are usually not recognized. While the research conducted by Gummesson [17], they concluded that the Bachelor of Northern Europe, especially from Finland and Sweden, feel free to design their own theory, and collaborate internationallyat the same time. Contributions, including early warning for services and business to business (B2B) marketing is ignored; dissatisfaction with the quality of service. The economic service is more than services sector.The insight of the relationship marketing andbetter marketing network is the real form of service.

\section{Personal sales}

School Leadership Academy sells its products directly to potential students through the class X and XI as a sales person, under supervisionof SMAN 10 Malang marketing teamas a sales manager.

"We have some media for advertising. One of them is a school website. Every single event is always uploaded and showed up to the public. The public are invited to give comment, critics and suggestion. By conducting this,there will be an interactive between parents and school"( $1^{\text {st }}$ informant $)$.

"Scholarship is only granted by the Government of Malang for 40 students from Malang resident"

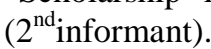

"We open the regular class which requires admission fee. Many students are from Papua, Kalimantan, and out of East Java Area enrolled through this line "( $1^{\text {stinformant }) .}$

"We always conduct of festival to accommodate junior high school students performance who have an achievement through their voice, math, Science, or other achievement which relate to their scholarships" ( $2^{\text {nd }}$ informant $)$.

"The Headmaster always invite principals, teachers, counsellors, or a students as the representative from other junior high schools" ( $1^{\text {stinformant}) . ~}$

"Yes, one of our marketing strategy is inviting junior high schools' principal, teachers and counsellors to have a meeting at this school" $\left(2^{\text {nd }}\right.$ informant $)$

"All the events, activities and achievements of the school as well as students are always uploaded to social media through the school's website" ( $1^{\text {stinformant})}$

"OnceNational Exam is held for XII class, both X and XI classesare off and back to their homes. During their holidays, they conducted promotion to junior high schools in their respective homelands. They are equipped byPowerpoint presentation which show a video profile of the school "( 1 stinformant $)$

\section{Supporting and Resisting Factors on the implementation of marketing communications strategies in SMAN 10 Malang (Leadership Academy)}

The supporting factors in the implementation of marketing communication strategy in Leadership Academy includes that the media campaign used has a wide range; it is formed a special team of marketing SMAN 10 Malang (Leadership Academy); there is a availability of funds, facilities, equipment and infrastructure to support the implementation of marketing communication strategy; there are teachers with good qualification; there are foreign and domestic cooperation; the enthusiasm of the students of SMAN 10 Malang (Leadership Academy) who are also as marketing school tools; the parents' loyalty to SMAN 10 Malang (Leadership Academy), which ultimately conduct the self-marketing called as Word Of Mouth (WOM).In accordance with the results of research conducted byFinne [18], they concluded that combining insights from marketing communications to the findings of research in relationship marketing, this study presents a holistic model that is based on the consumer's perspective and take into account the impact of all four factors messaging integration, offering researchers and marketers a useful tool to understand and manage marketing communications more effectively. The cost of education becomes the only factor resisting the implementation of marketing communication strategy.

The resisting factors in the marketing by this promotion media have been predicted and anticipated by the special marketing team in SMAN 10 Malang. Meaning that before marketing activity is conducted, SMAN 
10 Malang have analyzed its risks. The cost of education becomes the only factor resisting the implementation of marketing communication strategy.

\section{Conclusions And Recommendations}

The formulation of marketing communications strategy adopted by SMAN 10 Malang, namely by Marketing Mix is ranging from the communications products by offering the achievements and facilities, the communication rates by opening the education through paid path, the place communications by building a visual store merchandising, and the promotional communications as an element of discussion focus in the marketing communications applied by SMAN 10 Malang (Leadership Academy). Its formulation consists of a special mixture, namely advertising, sales promotion, public relations and publicity, personal selling.

The implementation of marketing communication strategy in SMAN 10 Malang is conducted after it prepares on the deep and strategic marketing communication planning, then the school communicates the marketing concept to the consumers collectively, this is called as the marketing communications mix including advertising, sales promotion, public relations and publicity, personal selling.

Advertising is a form of advertising communication by SMAN 10 Malang in terms of a communication tool using website and brochure. Sales Promotion, is a sales promotion given in the form of receiving scholarships to any prospective students from Malang, and in the form of gifts as education scholarships for competition / Olympic winners held by SMAN 10 Malang (Leadership Academy) for students of State / Private SMP / MTS throughout East Java Province.Public Relations and Publicity, is a marketing mix tool used by the school, in this case is by socialization conducted by the head of SMAN 10 Malang to representatives of State / Private SMP / MTS throughout Malang.Personal Selling means that the school sells its products, the Leadership Academy, directly to potential students as the sales person.

The supporting factors for the implementation of marketing communication strategy in SMAN 10 Malang are that it forms a special marketing team; the media promotions with a broad range; the availability of funds, facilities, infrastructure; the teaching staff with good qualifications; the foreign and domestic cooperation; the students' enthusiasm as marketer and the parents' loyalty; it has superiority by unique characteristic as a school with achievements and boarding education. The resisting factor for the implementation of marketing communication strategy at SMAN 10 Malang is the education cost for independent path which is considered to be fairly expensive; so, it decreases the interest of students with achievement outside Malang and with low economic conditions to enter SMAN 10 Malang.In terms of educational cost per month which is fairly expensive in senior high school level exceeding the university education cost per semester, the school should find a solution of education fund from sponsorships to reduce the education cost so that the students with low economic conditions can develop their talents to obtain achievement along with SMAN 10 Malang.

\section{References}

[1]. Duncan, Tom. 2005.Principles of Advertising \& IMC, 2nd Edition. North America.

[2]. Porter, Michael E. 2008. Competitive Strategy: Techniques for analyzing industries and competitors. Simon and Schuster.

[3]. Creswell, J. W. 2013. Research design: Qualitative, quantitative, and mixed methods approaches. New York: Sage publications.

[4]. Kotler, P., \& Keller, K. 2011. Marketing management 14th edition. Singapore: Prentice Hall.

[5]. Grant, R. M. 1997. The knowledge-based view of the firm: implications for management practice. Long range planning, 30 (3), 450-454.

[6]. Peattie, K., Peattie, S., \& Ponting, C. 2009. "Climate change: a social and commercial marketing communications challenge". EuroMed Journal of Business, 4(3): 270 - 286.

[7]. Urde, M., \& Koch, C. 2014. Market and brand-oriented schools of positioning. Journal of Product \& Brand Management.23 (7): 478-490.

[8]. Kotler, P., \& Armstrong, G. 2010. Principles of marketing. pearson education. Singapore: Prentice Hall

[9]. Pitta, D.A., Weisgal, M., and Lynagh, P. 2006. Integrating exhibit marketing into integrated marketing communications. Journal of Consumer Marketing. 23/3 (2006) 156-166

[10]. Cox, D. D., McLeod, S. 2014. "Social media marketing and communications strategies for school superintendents". Journal of Educational Administration, 52( 6) 850-868

[11]. Shimp, Terence A., \& Andrews, J. C. 2012.Advertising Promotion and Other Aspects of Integrated Marketing Communications. Cengage Learning.

[12]. Powers, T.L. 2012. "Early schools of marketing thought and marketplace evolution", Journal of Historical Research in Marketing, 4 (1): 190-206.

[13]. Oplatka, I., Brown, J.H. 2004. The research on school marketing. Journal of Educational Administration, 42 (3): $375-400$.

[14]. Geuens, M., Pelsmacker, P.D., Mast, G. 2002."Attitudes of school directors towards in-school marketing: an exploratory study", Young Consumers. Advertising \& Marketing to Children, 3 (3) 57-67.

[15]. Li, C.K., Hung, C.H. 2009. "Marketing tactics and parents' loyalty: the mediating role of school image". Journal of Educational Administration, 47(4): 477-489.

[16]. Tubin, D. 2015. "Relationship Marketing and School Success" In The Management and Leadership of Educational Marketing: Research, Practice and Applications. Advances in Educational Administration, 15: 159-181.

[17]. Gummesson, E., Gronroos, C. 2012. The emergence of the new service marketing: Nordic School perspectives. Journal of Service Management. 23 (4): 479-497.

[18]. Finne, A., \& Gronroos, C. 2009. Rethinking marketing communication: From integrated marketing communication to relation ship communication. Journal of Marketing Communications, 15( 2-3): 179-195. 